Article available at nttp://www.parasite-journal.org or nttp://dx.dol.org/10.1051/parasite/2000073185

\title{
ULTRASTRUCTURAL LOCALISATION OF CARBOHYDRATES IN FOUR MYXOSPOREAN PARASITES
}

\author{
MUÑOZ P.*, SITJÀ-BOBADILLA A.* \& ÁLVAREZ-PELLITERO P.*
}

\section{Summary :}

The existence and localisation of carbohydrates in four myxosporean parasites was investigated at transmission electron microscope, using lectin histochemistry techniques. The Myxosporea studied showed different lectin binding patterns. $N$ acetyl-glucosamine or its polymers were predominant in the valves of Leptotheca sp. and were also present in Sphaerospora dicentrarchi and Polysporoplasma sparis ones. Mannose and/or glucose terminals were mainly detected in S. dicentrarchi and $P$. sparis valves. Polar capsule walls were intensively recognised by Con-A in S. dicentrarchi and with medium intensity in $P$. sparis and Leptotheca sp. The polar filament was scarcely labelled except in Leptotheca sp. with BS-I. The sporoplasms of the studied parasites were stained with all the lectins tested with each myxosporea, except those of Leptotheca sp. with BS-I. Some structures of the developmental stages of Zschokkella mugilis and Leptotheca sp. were stained with BS-I. The possible role of these carbohydrate terminals found in the studied Myxosporea is discussed

KEY WORDS : lectins, ultrastructure, histochemistry, Myxozoa, Teleostei.
Résumé : Localisation ultrastructurale de GluCides ' CHEz QUatre MYXOSPORIDIES PARASITES

Une étude ultrastructurale précise la présence et la localisation de fractions glucidiques chez quatre myxosporidies par histochimie avec lectines. Les myxosporidies étudiées montrent différents patrons de reconnaissance avec les lectines. On observe une prédominance de $\mathrm{N}$-acétylglucosamine ou de ses polymères dans les valves de Leptotheca sp. et sa simple présence dans les valves de Sphaerospora dicentrarchi et Polysporoplasma sparis. Les terminaisons mannose et/ou glucose sont surtout trouvées dans les valves de $\mathrm{S}$. dicentrarchi et $\mathrm{P}$. sparis. Les parois des capsules polaires sont intensivement reconnues par la Con-A dans $S$. dicentrarchi et avec une moindre intensité dans $P$. sparis et Leptotheca sp. Les filaments polaires montrent un léger signal, exception faite de ceux de Leptotheca sp. intensivement marqués avec BS-I. Les sporoplasmes des parasites étudiés ont eté marqués par toutes les lectines trouvées dans chaque parasite, excepté ceux de Leptotheca sp. avec BS-I. Cette lectine marque quelques structures des stades de développement de Z. schokkella mugilis et Leptotheca sp. On discute le rôle des fractions glucidiques trouvées dans les myxosporidies étudiées, et on suggère la nécessité de nouvelles études pour éclaircir leur implication dans les relations hôte-parasite.

MOTS CLÉS : lectines, ultrastructure, histochimie, Myxozoa, Teleostei.

immunohistochemical methods at light microscope (Hedrick et al., 1992; Lukes et al., 1993; Marín de Mateo et al., 1996, 1997; Muñoz et al., 1999), the ultrastructural distribution of these components in Myxosporea has not yet been investigated.

Considering the likely importance of polysaccharides of an invading pathogen in the defence reaction of the host, in the current work we have examined the ultrastructural saccharide patterns of several myxosporean parasites, using lectin labelling techniques.

\section{MATERIALS AND METHODS}

\section{Tissue SAMPLES}

\footnotetext{
* Instituto de Acuicultura Torre de la Sal (CSIC), Ribera de Cabanes 12595, Castellón, Spain.

Correspondence: P. Álvarez-Pellitero.

Tel.: +34/964319500 - Fax: +34/964319509.

E-mail: alvarezp@iats.csic.es
}

$\mathrm{P}$ eriodic surveys of sea bass (Dicentrarchus labrax L.), gilthead sea bream (Sparus aurata L.), grey mullet (Mugil cephalus L.) and common dentex (Dentex dentex L.) were conducted for myxosporean 
parasite examination. They included fish of different stocks and ages from the Mediterranean area. Fish were overexposed to the anaesthesic MS-222 (Sigma Chemical Co., St. Louis, MO, USA), necropsied, and their organs excised for fresh and histological diagnosis. Parasitised organs were selected for ultrastructural studies.

\section{ULTRASTRUCTURAL LECTIN HISTOCHEMISTRY}

Sea bass intestines infected by Sphaerospora dicentrarchi, gilthead sea bream trunk kidneys harbouring Polysporoplasma sparis, grey mullet gall bladders infected by Zschokkella mugilis, and common dentex trunk kidney with Lepthoteca sp. were fixed in $1 \%$ $(\mathrm{v} / \mathrm{v})$ glutaraldehyde and $4 \%(\mathrm{w} / \mathrm{v})$ paraformaldehyde in $0.1 \mathrm{M}$ cacodylate buffer $\left(\mathrm{pH} 7.2,4^{\circ} \mathrm{C}\right)$, post-fixed in $0.1 \%(\mathrm{w} / \mathrm{v})$ cacodylic $\mathrm{OsO}_{4}$, dehydrated though a graded ethanol series, and embedded in Lowicryl K4M (Polysciences Ltd.). Ultrathin sections were collected on 200 mesh gold grids coated with Formvar. Grids were incubated with blocking buffer $(1 \%(\mathrm{v} / \mathrm{v})$ bovine serum albumin (Sigma) in $10 \mathrm{mM}$ Hepes, $\mathrm{pH}$ 7.5) at $20^{\circ} \mathrm{C}$ for $15 \mathrm{~min}$, and with biotinylated lectins at $20^{\circ} \mathrm{C}$ overnight. The concentrations of the lectins used in this study, their acronyms and major sugar specificities are listed in Table I. All the lectins were used following the manufacturer's instructions. Griffonia simplicifolia lectin (BS-I) (Vector Lab., Burlingame, CA, USA) was diluted in lectin buffer $(10 \mathrm{mM}$ Hepes, $0.15 \mathrm{M} \mathrm{NaCl}$, $0.1 \mathrm{mM} \mathrm{CaCl}, \mathrm{pH} 7.5)$, Canavalia ensiformis lectin (Con-A) (Vector) in lectin buffer plus $0.01 \mathrm{mM} \mathrm{MnCl}$, Sambucus nigra lectin (SNA) (Vector) in lectin buffer plus $0.008 \%$ sodium azide, and Triticum vulgaris lectin (WGA) (Sigma) in $0.05 \mathrm{M}$ Tris, $0.15 \mathrm{M} \mathrm{NaCl}$, $1 \mathrm{mM} \mathrm{MnCl}_{2}, 1 \mathrm{mM} \mathrm{MgCl}, 0.1 \mathrm{mM} \mathrm{CaCl}, 0.5 \mathrm{mg} / \mathrm{ml}$ polyethylene glycol, $\mathrm{pH}$ 7.5. In all cases, the lectin concentration used was $5 \mu \mathrm{g} / \mathrm{ml}$. After rinsing in $10 \mathrm{mM}$ Hepes, grids were incubated with streptavidin conjugated with $15 \mathrm{~nm}$ colloidal gold particles (Biocell) in $10 \mathrm{mM}$ Hepes $(1: 25)$ at $20^{\circ} \mathrm{C}$ for $1 \mathrm{~h}$. Negative controls were obtained using $10 \mathrm{mM}$ Hepes instead of each lectin in the first incubation. Grids were washed with $10 \mathrm{mM}$ Hepes and bidistilled water, and stained with uranyl acetate and lead citrate. They were examined in a Hitachi H-800 MET operating at $80 \mathrm{kV}$. An equal amount of each lectin and its corresponding blocking $\operatorname{sugar}(0.2 \mathrm{M})$ were incubated overnight at $20^{\circ} \mathrm{C}$, before application of the solutions to the grids, as a control for binding specificity. The blocking sugars used were lactose (Sigma) for BS-I, $\alpha$-N-acetyl-D-glucosamine (Sigma) for WGA, methyl- $\alpha$-D-mannopyranoside (Sigma) for Con-A, and $\mathrm{N}$-acetylneuraminic acid (Sigma) for SNA. Each parasite was assayed with the lectins which gave the clearest positive results at light microscope (Muñoz et al., 1999), as listed in Table I.

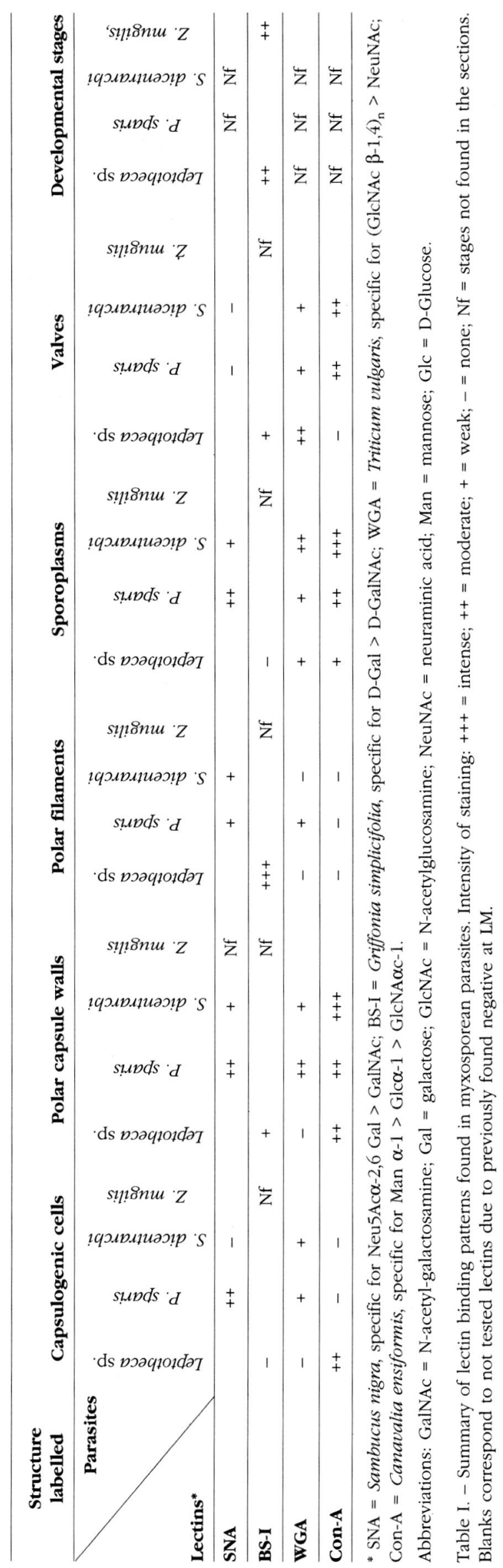




\section{RESULTS}

T The ultrastructural localisation of polysaccharides in myxosporean parasites by different lectins is summarised in Table I.

Con-A stained moderately the capsulogenic cells and the polar capsule wall, and weakly the sporoplasms of Leptotheca sp. Some labelling was observed in the cytoplasm, the nucleus and the mitochondria of capsulogenic cells in immature spores with this lectin (Figs. 1, 2). WGA labelled the valves of this parasite and very weakly their sporoplasms. BSI bound strongly to the polar filaments and weakly to the polar capsule walls and the valves of Leptotheca sp. (Fig. 3). In developmental stages, moderate labelling was seen in the cytoplasm of primary and secondary cells.

Con-A bound moderately to the polar capsule wall of Polysporoplasma sparis spores and to their valves and sporoplasms. WGA labelled moderately the polar capsule wall, and weakly the capsulogenic cells, the polar filament, the sporoplasms and the valves of this parasite (Fig. 4). SNA stained moderately the sporoplasms (Fig. 5), the polar capsule wall and the capsulogenic cells of $P$. sparis, and weakly the polar filaments. Some gold particles were also observed in mitochondria of sporoplasms and capsulogenic cells with these three lectins, mainly with SNA.

Sphaerospora dicentrarchi lectin histochemistry with Con-A (Fig. 6) resulted in a strong staining of sporoplasms and polar capsules (mainly the walls), and a moderate labelling of valves. WGA bound moderately to the sporoplasms of $S$. dicentrarchi and weakly to capsulogenic cells, valves and the polar capsule wall (Fig. 7). SNA stained weakly the sporoplasms, the polar capsule walls and the polar filaments of this parasite.

BSI stained some structures of Zschokkella mugilis developmental stages (Figs. 8, 9). The most intense staining was located in the nucleus. Some scarce gold particles were scattered in the cytoplasm of the primary, secondary and tertiary cells, and also in some of their mitochondria.

\section{DISCUSSION}

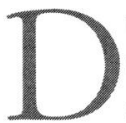
ue to the multifaceted properties of lectins, they have been used as probes to investigate cell surface structures and functions (Slifkin \& Doyle, 1990). Using ultrastructural studies, information can be obtained not only about the presence of specific carbohydrates but also on their location. The Myxosporea studied showed different ultrastructural lectin binding patterns. Previous observations at light microscope (LM) on the same parasites (Muñoz et al.,
1999) demonstrated that valves and polar capsules are the main stained structures with the different lectins. This general staining pattern was in part confirmed by the present ultrastructural observations. The exact binding location was accurately determined and some differences were seen with respect to the LM observations, mainly regarding the staining intensity.

Parasitic surfaces are involved in many host-parasite interactions, and are made up of oligosaccharide side chains of glycoproteins and glycolipids (Peters, 1988). In our study, spore valves were stained mainly with two lectins, WGA and Con-A. WGA stained them in all the parasites assayed. This lectin recognises mainly $\mathrm{N}$-acetyl-glucosamine and, to less extent, sialic acid. In Sphaerospora dicentrarchi, the absence of binding to the valves with SNA (already observed at LM, Muñoz et al., 1999) was confirmed in this ultrastructural study. Thus, the presence of $\mathrm{N}$-acetyl-glucosamine or its polymers was demonstrated. Con-A bound to the valves of two parasites, Sphaerospora dicentrarchi and Polysporoplasma sparis, though moderately. Therefore, some mannose and/or glucose terminals must also be present. Thus, this ultrastructural study demonstrated the predominance of $\mathrm{N}$-acetyl-glucosamine or its polymers in the valves of Leptotheca sp. and its presence in $P$. sparis and $S$. dicentrarchi, whereas mannose and/or glucose terminals were mainly present in $S$. dicentrarchi and $P$. sparis valves. It is probable that $\mathrm{N}$-acetylglucosamine or its polymers have a protective and structural role in these spores. Chitin, the polymer of $\mathrm{N}$-acetyl-glucosamine, is a structural component of the wall of many fungi and it can show a different distribution pattern in the wall parts, as in the deuteromycete Chalara elegans (Dumas-Gaudot, 1992) or the hyphomycete Nomuraea rileyi (Pendland \& Boucias, 1992).

Polar capsules constituted another frequently stained structure with the different lectins used in the present study. The wall of the polar capsules was intensively recognised by Con-A in $S$. dicentrarchi, and with medium intensity in P. sparis and Leptotheca sp., whose capsulogenic cells (mainly in immature spores) were also stained. Polar filaments were scarcely recognised by the different lectins, and the most intense staining was obtained with BSI in Leptotheca sp. Thus, galactose and/or $\mathrm{N}$-acetyl-galactosamine seem to be present in this structure. In addition, only SNA detected slightly the polar filament of $P$. sparis and $S$. dicentrarchi.

An outstanding result of this ultrastructural study is the staining of the sporoplasms of most parasites with all the lectins tested with each myxosporea, except those of Leptotheca sp. with BS-I. However, differences were observed in their staining pattern. The strongest binding was obtained with Con-A in $S$. dicentrarchi, and 


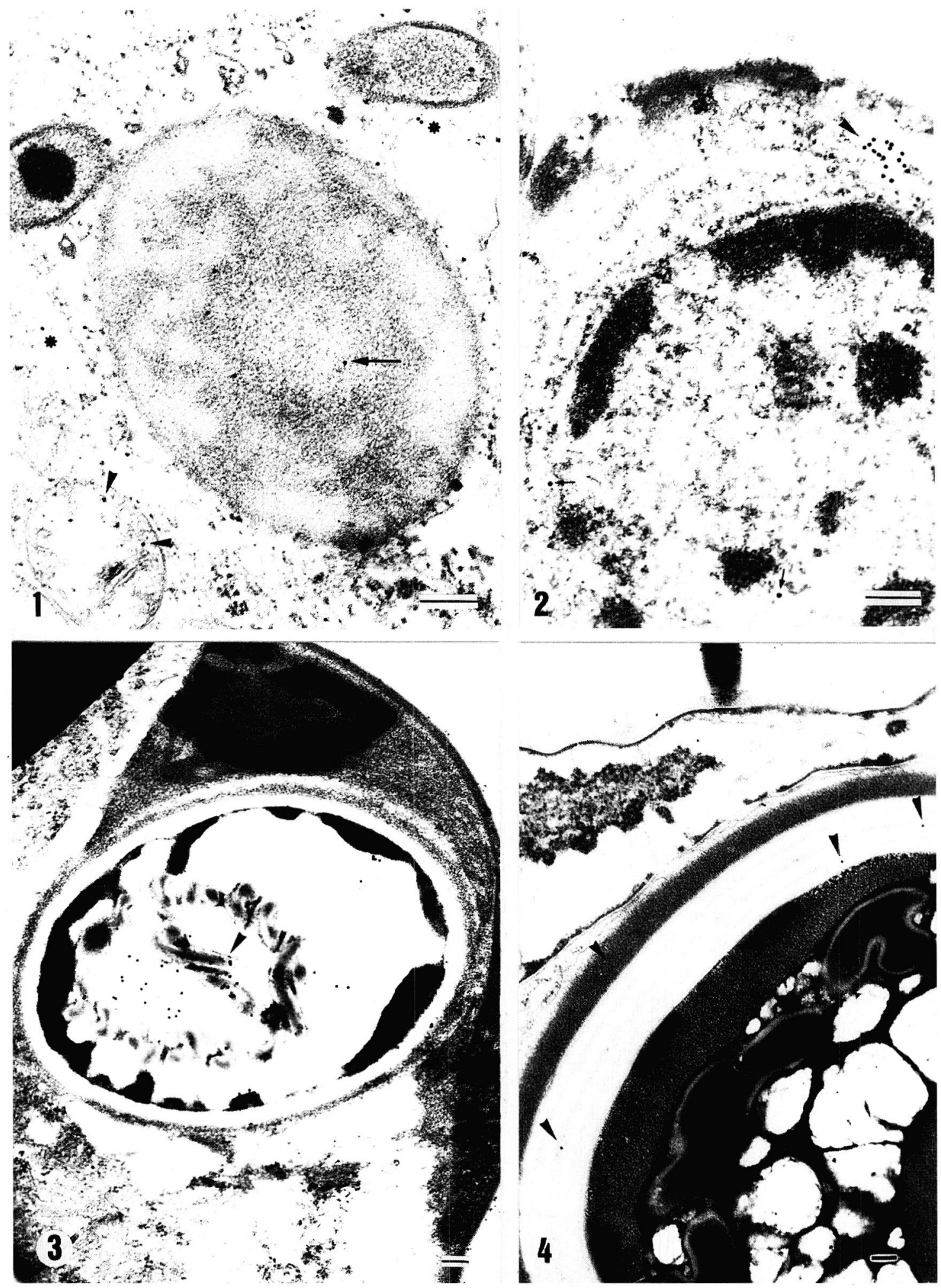

Figs. 1 to 4. - Transmission electron microscopy images of myxosporean parasites in tissue sections stained with lectins. Figs. 1 to 3. Leptotheca sp. from common dentex trunk kidney. Figs. 1, 2. Sections of immature spores stained with Con-A. Fig. 1. - Note the labelling in mitochondria (arrowheads), in the cytoplasm $\left({ }^{*}\right)$, in the capsular primordium (arrow) and in the external tube. Fig. 2. - Note the scarce labelling in the nucleus of a capsulogenic cell (arrows) and a group of gold particles associated to rough endoplasmic reticulum (arrowhead). Fig. 3. - Section of a mature spore stained with BS-I. A distinct labelling in the polar filament is observed (arrowhead). Fig. 4. - Polysporoplasma sparis in gilthead sea bream trunk kidney stained with Con-A. Note the staining of the polar capsule wall (arrowheads) and valves. Bars $=0.2 \mu \mathrm{m}$. 


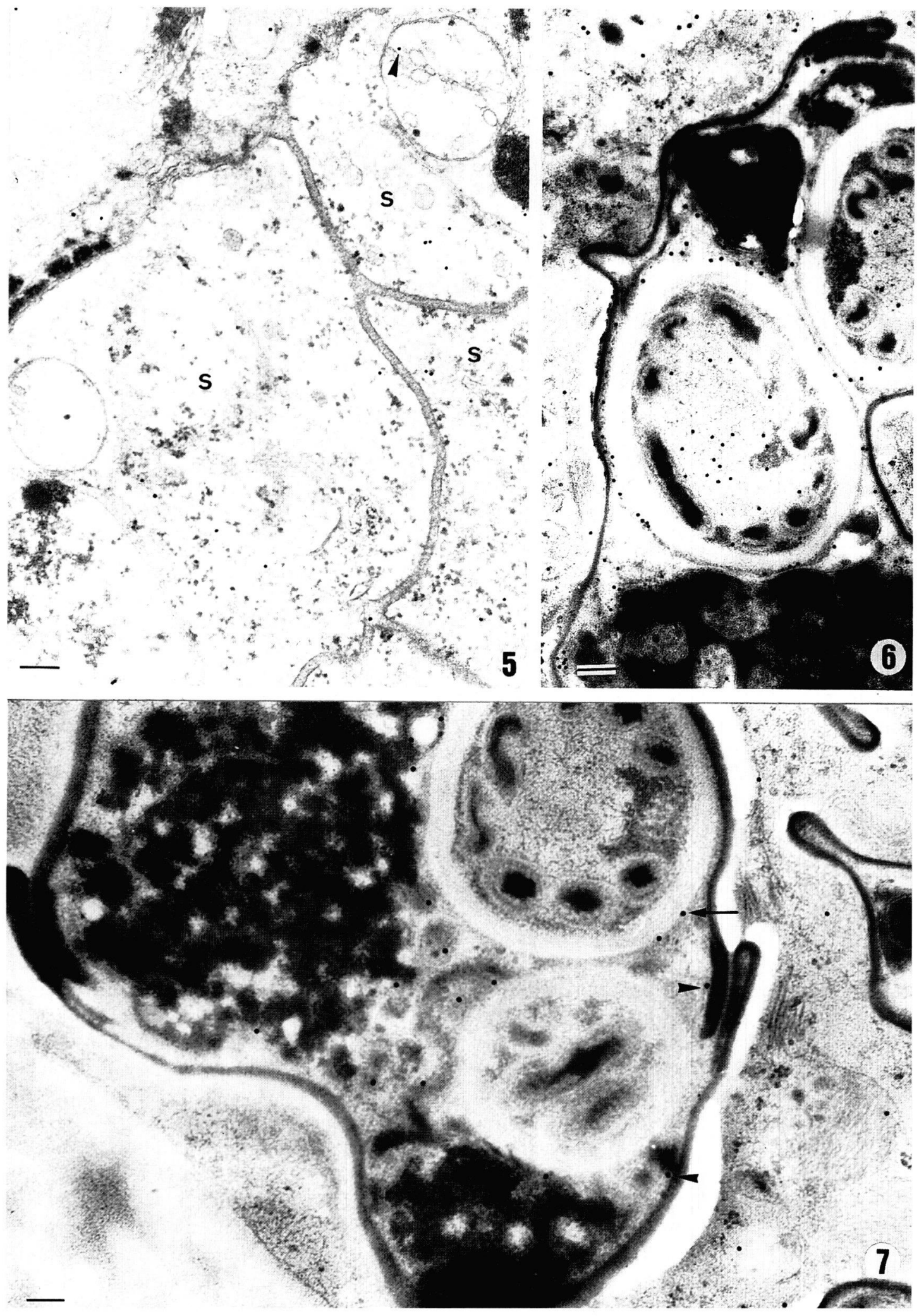

Figs. 5 to 7. - Transmission electron microscopy images of myxosporean parasites in tissue sections stained with lectins. Fig. 5. - Polysporoplasma sparis in gilthead sea bream trunk kidney stained with SNA. Note the scattered labelling of the sporoplasms (S) and the very scarce staining in their mitochondria (arrowhead). Figs. 6, 7. Sphaerospora dicentrarchi in sea bass intestine. Fig. 6. - Staining with Con-A. Strong labelling in polar capsules and moderate staining in valves. Fig. 7. - Staining with WGA. Moderate staining in sporoplasms and weak labelling of polar capsule walls (arrow) and valves (arrowheads). Bars $=0.2 \mu \mathrm{m}$. 


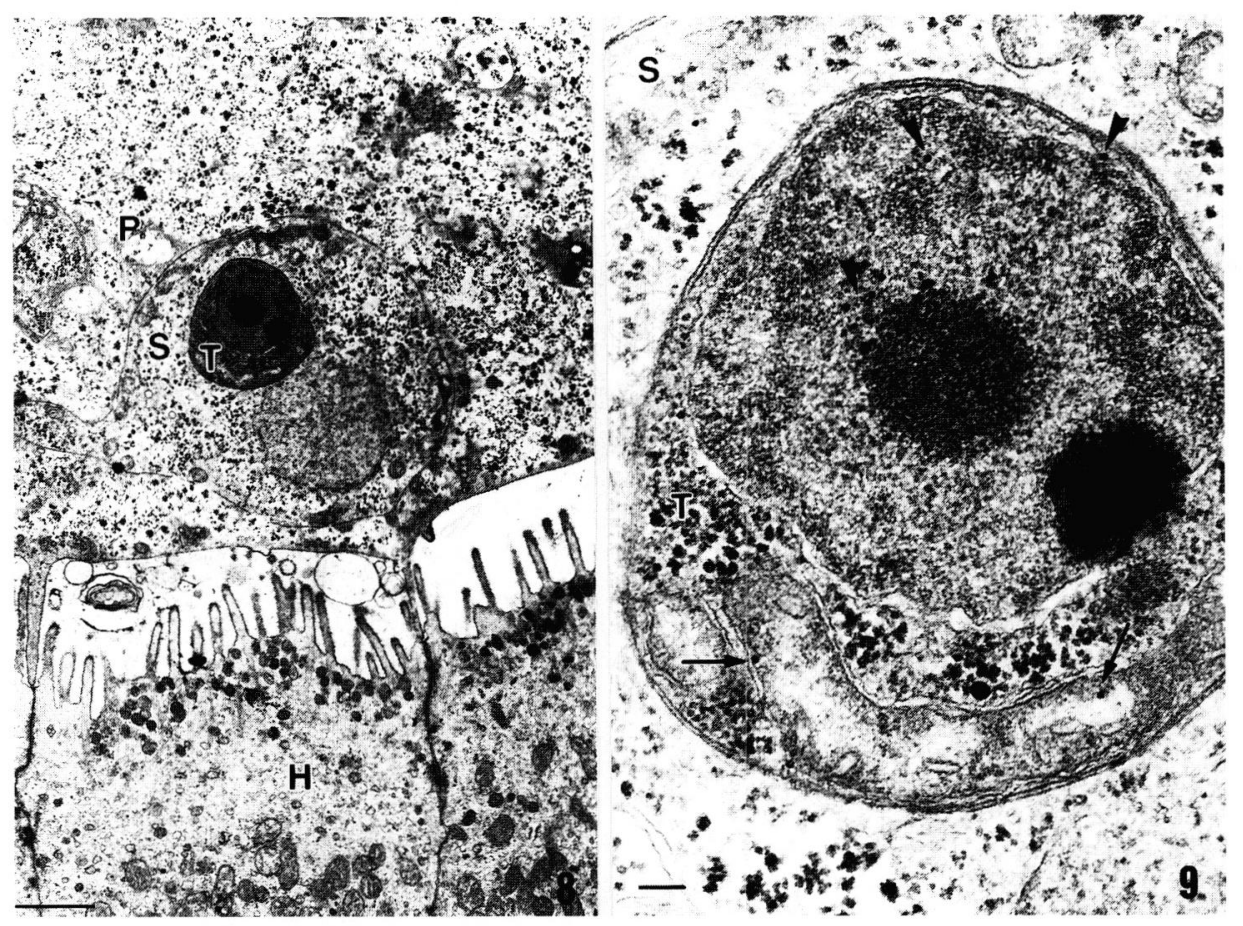

Figs. 8, 9. -- Transmission electron microscopy images of Zschokkella mugilis in a mullet gall bladder section stained with BS-I. Fig. 8. - Primary cell $(\mathrm{P})$ attached to the epithelium of the host $(\mathrm{H})$, containing secondary (S) and tertiary ( $\mathrm{T})$ cells. Bar $=1 \mu \mathrm{m}$. Fig. 2. - Detail of these $\mathrm{S}$ and $\mathrm{T}$ cells showing the scarce labelling in the cytoplasm and mitochondria (arrows) and some staining in the nucleus (arrowheads). Bar $=0.1 \mu \mathrm{m}$ a medium intensity of staining was detected with ConA and SNA in P. sparis, and with WGA in S.dicentrarchi.

Only in the case of Zschokkella mugilis and Leptotheca sp. were some developmental stages observed in the sections and some of their structures were stained with BS-I. D-galactose or $\mathrm{N}$-acetyl D-galactosamine residues have also been detected in the developmental stages of other myxosporean parasites such as PKX (the causative agent of proliferative kidney disease) (Marín de Mateo et al., 1997).

The ultrastructural binding pattern of a polyclonal antiserum raised against $S$. dicentrarchi (Muñoz et al., 1998) was, in part, coincident with that obtained with Con-A. As the carbohydrate components of glycoproteins can be antigenic determinants (Rafferty \& Mulcahy, 1988; Roth et al., 1997), it seems possible that some of the epitopes recognised by this polyclonal antiserum could be the carbohydrates detected in this study.

The most important residues, which probably play a role in the host-parasite interaction, include mannose/glucose, sialic acid and galactose, as it has been demonstrated in different pathogens. Mannose and/or glucose have been detected by Con-A binding in other fish parasites, as Cryptobia spp. (Feng \& Woo, 1998). Some mammalian parasites, as Entamoeba bistolytica, Acanthamoeba sp., Trichomonas vaginalis, Pneumocystis carinii or Leishmania spp. (see Slifkin \& Doyle, 1990) also showed Con-A-mannose interactions which have been associated to virulence or infectivity in some cases. Moreover, the role of macrophage man- nose receptors in innate defence against a variety of microorganisms is well known (Drickamer \& Taylor, 1993; Holmskov et al., 1994). Sialic acids are important regulators of cellular and molecular interactions, and they can mask recognition sites or serve as recognition determinants. However, little is known about the role of sialic acids in the biology of parasites. Galactose plays a role in fungi-insect interactions (Penland \& Boucias, 1993) or can act as a storage product (Dumas-Gaudot et al., 1992).

The terminals demonstrated in our Myxosporea might also play a role in the host-parasite relationship. Those found in the spore surface or in polar filaments could be involved in the invasion and dispersion within the hosts, including a putative invertebrate intermediate host, if the complex life cycle demonstrated for some fresh water myxosporean parasites (Wolf \& Markiw, 1984; Bartholomew et al., 1997; Lin et al., 1999) takes also place in these marine myxosporoses. Different membrane and humoral lectins have been demonstrated in invertebrates (Vasta \& Ahmed, 1996), and some of them are involved in host-pathogen interactions (Penland \& Boucias, 1992; Welburn \& Maudlin, 1999). Spores can also interact with the defence system of the fish host, especially in the case of inflammatory reactions. The developmental stages in the fish could also be involved in the host-parasite interaction, both in the dispersion of proliferative stages or in possible fish-to-fish infection. Therefore, further research is needed to clearly ascertain the role of the carbohydrate terminals in the myxosporean parasites and in the host-parasite relationship. 


\section{ACKNOWLEDGEMENTS}

T This work was supported by research grants from the Spanish Ministerio de Educación y Cultura No. AGF95-0058 and MAR98/1000. Pilar Muñoz received a grant from the Spanish Ministerio de Educación y Cultura. We are thankful to technicians from the Electron Microscopy Service of the University of Barcelona and to the Instituto Español Oceanográfico at Mazarrón (Murcia) for providing some of the fish.

\section{REFERENCES}

Alvarez-Pellitero P. \& Sitjà-Bobadilla A. Pathology of Myxosporea in marine fish culture. Diseases of Aquatic Organisms, 1993, 17, 229-238.

Bartholomew J.L., Whipple M.J., Stevens D.G. \& Fryer J.L. The life cycle of Ceratomyxa shasta, a myxosporean parasite of salmonids, requires a freshwater polychaete as an alternate host. Journal of Parasitology, 1997, 83, 859-868.

Bauer O.N., Egusa S.Y. \& Hoffman G.L. Parasitic infections of economic importance in fishes. In: Review of Advances in Parasitology, Slusarski W. (ed.) Polish Science Publications, Warszawa, 1981, 425-443.

Company R., Sitjà-Bobadilla A., Pujalte M.J., Garay E., Alvarez-Pellitero P. \& Pérez-Sanchez J. Bacterial and parasitic pathogens in cultured common dentex (Dentex dentex L.). Journal of Fish Diseases, 1999, 22, 299-310.

Drickamer K. \& TAYlor M.E. Biology of animal lectins. Annual Review of Cell Biology, 1993, 9, 237-264.

Dumas-Gaudot E. \& Tahiri-Alaoui A. Cytochemical localization of some polysaccharidic components in the cell walls of Chalara elegans during its life cycle. Canadian Journal of Microbiology, 1992, 38, 828-837.

El-Matbouli M., Fischer-Scherl T. \& Hoffmann R.W. Present knowledge on the life cycle, taxonomy, pathology, and therapy of some myxosporea spp. important for freshwater fish. Annual Review of Fish Diseases, 1992, 2, 367-402.

FENG S. \& WOO P.T.K. Identification of carbohydrates on the surface membrane of pathogenic and nonpathogenic piscine haemoflagellates, Cryptobia salmositica, C. bullocki and C. catostomi (Kinetoplastida). Diseases of Aquatic Organisms, 1998, 32, 201-209.

Hedrick R.P., Marín De Mateo M., Castagnaro M., Monge D. \& Kinkenlin P. Rapid lectin-based staining procedure for detection of the myxosporean causing proliferative kidney disease in salmonid fish. Diseases of Aquatic Organisms, 1992, 13, 129-132.

Holmskov U., Malhotra R., Sim R.B. \& Jensenius J.C. Collectins: collagenous C-type lectins of the innate immune defense system. Immunology Today, 1994, 15, 67-73.

LIN D., HANSON L.A. \& POTE L.M. Small subunit ribosomal RNA sequence of Henneguya exilis (Class Myxosporea) identifies the actinosporean stage from an oligochaete host. Journal of Eukaryotic Microbiology, 1999, 46, 66-68.
LuKes J., Volf P. \& Lom J. Detection of chitin in spores of Myxobolus muelleri and M. subepithelialis (Myxosporea, Myxozoa). Parasitology Research, 1993, 79, 439-440.

Marín De Mateo M., McGeorge J., Morris D. \& Kent M.L. Comparative studies of PKX and Sphaerospora spp. from salmonids using lectin and monoclonal antibody staining techniques. Journal of Fish Diseases, 1996, 19, 55-63.

Marín De Mateo M., Bovo G., Comuzzi M. \& Adams A. Lectin histochemical studies on Sphaerospora sp. (Myxosporea) from Italian brown trout, Salmo trutta L. Journal of Fish Diseases, 1997, 20, 51-58.

Muñoz P., Sitjà-Bobadilla A. \& Alvarez-Pellitero P. Immunohistochemical characterisation of a polyclonal antibody against Sphaerospora dicentrarchi (Myxosporea: Bibalvulida), a parasite from sea bass (Dicentrarchus labrax L.) (Teleostei: Serranidae). Parasitology Research, 1998, 84, 733-740.

Muñoz P., Palenzuela O., Álvarez-Pellitero P. \& SitjàBobadilla A. Comparative studies on carbohydrates of several myxosporean parasites of fish using lectin histochemical methods. Folia Parasitologica, 1999, 46, 241 247.

Pendland J.C. \& Boucias D.G. Ultrastructural localization of carbohydrate in cell walls of the entomogenous hyphomycete Nomuraea rileyi. Canadian Journal of Microbiology, 1992, 38, 377-386.

Pendland J.C. \& Boucias D.G. Variations in the ability of galactose and mannose-specific lectins to bind to cell wall surfaces during growth of the insect pathogenic fungus Paecilomyces farinosus. European Journal of Cell Biology, 1993, 60, 322-330.

Peters W. Surface coat. In: Parasitology in Focus. Facts and trends, Melhorn H. (ed.), Springer-Verlag, Berlin, 1988, 197-219.

RAFFERTY M.D.\& MulCaHY M.F. Is PKX related to Sphaerospora? Bulletin of the European Association of Fish Pathologists, 1988, 8, 47.

Roth A., Weeke J., Karsten V. \& Janistschke K. Light and electron microscopy study of carbohydrate antigens found in electron-lucent layer of Pneumocystis carinii cysts. Parasitology Research, 1997, 83, 177-184.

SLIFKIN M. \& DOYLE R.J. Lectins and their application to clinical microbiology. Clinical Microbiology Reviews, 1990, 3 , 197-218.

VASTA G.R. \& Ahmed H. Animal lectins as cell surface receptors: current status for invertebrate species. In: Signaling mechanisms in protozoa and invertebrates. Progress in molecular and subcellular biology, Csaba G. \& Müller W.E.G. (eds.), Springer, Berlin, 1996, 158-182.

WelbuRn S.C. \& MaUdin I. Tsetse-Trypanosome interactions: rites of passage. Parasitology Today, 1999, 15, 399-403.

WOLF K. \& MARKIW M.E. Biology contravenes taxonomy in the Myxozoa: new discoveries show alternation of invertebrate and vertebrate hosts. Science, 1984, 225, 14491452 .

Reçu le 10 février 2000

Accepté le 31 mai 2000 